Arne De Boeck, et al., Int. J. of Safety and Security Eng., Vol. 4, No. 1 (2014) 38-53

\title{
OPTIMIZING SECURITY POLICIES AND PRACTICES IN THE PORT OF ANTWERP: ACTORS' PERCEPTIONS AND RECOMMENDATIONS
}

\author{
ARNE DE BOECK ${ }^{1}$, GENSERIK RENIERS ${ }^{2,3,6}$, MARC COOLS $^{1,4}$, MARLEEN EASTON $^{5}$ \& \\ EVELIEN VAN DEN HERREWEGEN ${ }^{1,2}$ \\ ${ }^{1}$ Department of Penal Law and Criminology, Ghent University, Universiteitsstraat 4, 9000 Ghent, Belgium. \\ ${ }^{2}$ Antwerp Research Group on Safety and Security (ARGoSS), University of Antwerp, \\ Prinsstraat 13, 2000 Antwerp, Belgium. \\ ${ }^{3}$ Centre for Economics and Corporate Sustainability (CEDON), HUB, KULeuven, \\ Warmoesberg 26, 1000 Brussels, Belgium. \\ ${ }^{4}$ Research Group Cris, Free University of Brussels (VUB), Pleinlaan 2, 1050 Brussels, Belgium. \\ ${ }^{5}$ Department of Administration and Management, University College Ghent (HoGent), \\ Kortrijksesteenweg 14, 9000 Ghent, Belgium. \\ ${ }^{6}$ Safety and Security Science, Faculty TPM, Delft University of Technology, \\ Jaffalaan 5, 2628 BX Delft, The Netherlands.
}

\begin{abstract}
The Port of Antwerp is the second largest harbor in Europe. Security and policing activities within the port area are frequent, diversified and involve many different actors (federal and local goverments, law enforcement agencies, emergency services etc.). To make security measures work, it is not only important that responsibilities and competences of these actors are unambiguously fixed but also that there is sufficient cooperation and coordination among them. In this article we extensively analyze existing policy arrangements within the Port of Antwerp region for four security phenomena, that is, port-related crime, threats, emergency situations and events and incidents. To this end, we developed an innovative assessment scheme to analyze and evaluate multi-actor collaborations. Based on extensive in-depth interviewing and actors' perceptions and points of consideration, in combination with state-ofthe-art insights described in literature, we formulate recommendations on how to improve the present security arrangements situation, within current limitations (short-term), as well as thinking out of the box (long-term).

Keywords: Port security, qualitative research, emergency management, crime investigation, threat assessment, event management, policing.
\end{abstract}

\section{INTRODUCTION}

The current port area of Antwerp is one of the vastest harbor areas worldwide. It has a surface area of 13,057 hectares. In the area, some 409 kilometers of roads, 1,061 kilometers of railways, 350 kilometers of pipelines and 157 kilometers of quays are situated. Some 150,000 people work in the harbor area, and some 900 private companies are active in the area. In 2011, 15,240 sea vessels visited the Port of Antwerp, and 187,151,714 metric tons of cargo was loaded and unloaded.

This brief overview of some of the harbor area's characteristics illustrates the importance of security within this area. Security in an international port such as that of Antwerp incorporates different elements. Harbor security on the one hand indicates harbor-related criminal acts such as international drug traffic, smuggling, scam with vehicles and waste, etc. On the other hand, harbor security is also linked with protecting the port against economic and human threats such as terrorist attacks. Harbor security also involves preventing and managing emergency situations and incidents, as well as the planning and organization of events. In fact, every one of the four mentioned phenomena (that is, (i) port-related crime, (ii) threats, (iii) emergency situations, and (iv) events and incidents) is very important with respect to 
harbor security and requires attention in our study. It is obvious that the four mentioned security phenomena do not form completely mutually exclusive classes and that they in fact all overlap at some level and/or to some extent/degree with respect to security activities. This has no impact on our study results, since we look at the single phenomena from a multi-actor perspective.

From a socio-economic perspective, the Antwerp harbor area can be considered as one territorial region. Nonetheless, a number of jurisdictional lines are present within the area. The river Scheldt separates the area not only into a left bank and a right bank but also into two distinct administrative and judicial parts. The first administrative part concerns Antwerp, whereas the second administrative part concerns Eastern-Flanders. The port of Antwerp is located not only in two Belgian provinces (Antwerp and Eastern-Flanders) and in three municipalities (Antwerp, Zwijndrecht and Beveren) but also in two judicial districts (Antwerp and Dendermonde). Evidently, the possible problems in a large port area may not always be restricted to one municipality, one province or one judicial district. Moreover, the port area is still expanding on the left bank, and thus current problems may be relocated and/or extended. Hence, there seems to be a need for a cross-jurisdictional security approach in the harbor area.

As a result of the multi-faceted nature of harbor security and the administrative and judicial complexity of the port area, a considerable number of 'actors' can be identified. Within the port of Antwerp, the actors involved with harbor security can roughly be classified into three broad categories:

(i) Governmental bodies that have people in different departments who may deal with security. They can be listed as the Belgian Ministry of Home Affairs, the Belgian Ministry of Justice, the Flemish regional government, the governors of the provinces of Antwerp and Eastern-Flanders, the mayors of the city of Antwerp and the municipalities of Zwijndrecht and Beveren and the municipal port authority of Antwerp.

(ii) Those involved with - and responsible for - security from a justice and policing perspective. The Belgian police is organized at two levels: federal and local. In the port of Antwerp, three local police forces (Antwerp, Zwijndrecht and Beveren) and five federal policing bodies (the federal judicial police of Antwerp and Dendermonde, the federal administrative police of Antwerp and Dendermonde and the federal maritime police) are operational. Judicial authorities include the public prosecutors of the judicial districts of Antwerp and Dendermonde. Finally, the Belgian intelligence and security services can also be included in this category.

(iii) Those involved with - and responsible for - security from an inspection and rescue viewpoint. These include, among others, the Customs, the Environmental Inspection, and the fire brigades.

Moreover, within a port area, a large number of private companies also have to be taken into account for several reasons. The ISPS Code obliges those companies with a quay to have stringent security measures in place. The International Ship and Port Facility Security Code (ISPS Code) is a set of international mandatory regulations that were developed to enhance the security of ships and port facilities. The rules were created in response to the perceived threats to ships and port facilities in the wake of the 9/11 attacks in the United States. The Code gives the owners and crew of ships and operators of port facilities a constant risk management responsibility. ISPS went into effect on July 1st 2004.

This paper reports the results of a qualitative case study examining current security arrangements in the port of Antwerp and the actors' perceptions of this current situation. 
Taking a 'public policy perspective', we predominantly focus on (i) division of responsibilities and competences and (ii) cooperation and coordination between different state actors. The aim of this study was two sided. First, the goal was to obtain more insight into the ways the four above-mentioned security phenomena (port-related crime, threats, emergency situations and events and incidents) are currently being approached in the port area. The study secondly aimed to perform a gap analysis based on the insights and perceptions of the different actors involved in port security. The objective of this gap analysis was to identify the weak and strong points of the current harbor security setting. More specifically, the extent to which the policies (strategic level) and practices (operational level) of the different actors are sufficiently integral and integrated were focused upon. This gap analysis allows us to make recommendations for further improving the port's security arrangements.

In section 2, we describe the theoretical framework that we conceptualized to evaluate the existing level of integration and integrality of different security arrangements within the port area. Section 3 thereafter provides the research methodology and detailed information on the data and the methodology used. Section 4 presents the research results per security phenomenon and discusses these. We draft conclusions in the final section.

\section{THEORETICAL FRAMEWORK TO STUDY INTEGRAL AND INTEGRATED SECURITY ARRANGEMENTS}

In this research, integral indicates 'comprehensive' or 'global'. More specifically, approaching security phenomena in an integral way means that attention is not only given to reactive processes (taking measures to respond to security problems when they occur) but also to proactive processes (identifying and taking into account security problems that might occur in the future), preventive processes (taking measures to prevent already identified security problems from occurring), preparatory processes (taking measures to ensure sufficient preparation to deal with security problems in case they occur) and recovery processes (taking measures that lead to recovery from the consequences of problems and a return to the 'normal' situation). The distinction between these processes is based on the so-called 'safety chain approach' that was developed in 1993 in the Netherlands to evaluate risk policy for chemical industries and fire safety [1]. An integrated approach exists when there is a sufficient amount of coordination between the policies and/or practices of different actors involved in the above-mentioned processes, both at operational (short-term and hands-on) and strategic (long-term and policy-oriented) level.

Several issues need to be addressed when elaborating and implementing an integral and integrated security approach where many actors are involved. According to their position on two principal axes - the 'strategic level' versus the 'operational level' and 'actor' (integrated) versus 'process' (integral) - we distinguish between the following four issues (see Fig. 1): (I) the definition problem, (II) the communication problem, (III) the responsibility problem, and (IV) the handling problem.

To analyze and to evaluate multi-actor collaborations, the four areas of Fig. 1 need to be investigated and, where possible, optimized. These four possible problem areas are briefly discussed hereunder.

I. Definition problem: strategic decisions at actor level

Defining the problem is widely seen as the necessary first step in the policy process [2]. To be able to attain an integrated approach of security phenomena, it is essential that there is a sufficient degree of consensus between actors about what constitutes a security problem and how important that problem is. The importance of a problem can be 


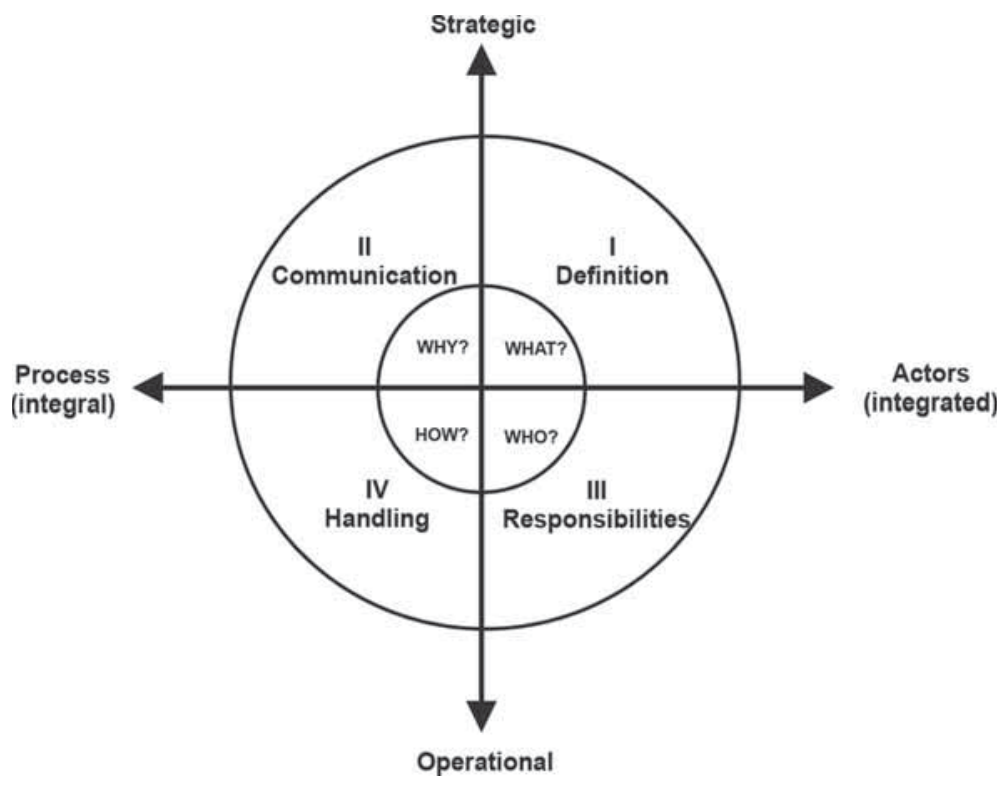

Figure 1: Assessment scheme.

determined by a risk assessment. In case of security risks, three parameters play a role in this assessment: threat, vulnerability and consequence [3]. Threat is the probability of an incident and consequence is the loss given the occurrence of an incident. In case the security risk includes the possibility of an attack (e.g. terrorists), vulnerability may refer to the probability of 'success'.

In this study we focus on the extent to which a common problem definition of the four security phenomena (port-related crime, threats, emergency situations, and events and incidents) is available that can lay the fundamental groundwork for the actions of different actors.

II. Communication problem: process-related decisions at the strategic level

Adequate communication between actors is essential for integral and integrated security. Inadequate communication may lead to unawareness of problem(s) or lack of knowledge and/or information about measures taken by other actors with respect to similar security problems. Furthermore, consultation and communication between different actors helps in constructing shared perceptions of reality, which is beneficial for a targeted approach of any problem. In this study we examine formal consultation and communication structures that currently exist in the port area to bring together different actors involved in port-security.

III. Responsibility problem: operational decisions at actor level

Dividing the actors' responsibilities and competences in a transparent way, per security phenomenon, is essential. If there is no clearness about this, it is possible that the problem, although it would be well defined and despite its handling would be discussed, is not dealt with. Furthermore, indistinctness regarding the competences and responsibilities may lead to tensions between the actors, in turn leading to inefficient tackling of crime and security problems. Crawford [4] puts it as follows: 'the problem of many 
hands where so many people contribute that no one contribution can be identified; and if no person can be held accountable after the event, then no one needs to behave responsibly beforehand. As authority is 'shared', it becomes difficult to disentangle and can become almost intangible'.

IV. Handling problem: process-related decisions at the operational level

An integral approach requires the actors to agree with one another on the manner to tackle the problem. There has to be consensus about the type of approach: pro-active, preventive, preparatory, reactive, curative and/or a mixed approach. Similarly, there has to be a clear view of how measures of one actor influence the efficiency and effectiveness of actions of other actors.

Remark that this theoretical framework can be used for any approach where an integral and integrated approach involving multi-actor collaborations, is desired. The assessment scheme can thus be used to study the security arrangements in an analytical and systematic way within any port area worldwide.

\section{RESEARCH METHODOLOGY}

As the object of this study is the description and evaluation of complex security arrangements in their real-life context (i.e. in the port of Antwerp), we adopted a descriptive case study design [5]. Data were collected in two ways: through a study of documents and through in-depth expert interviews. First, an extensive study of the following types of documents was carried out: legislation, official policy documents, working documents, annual reports, mutual agreements, protocols, etc. Some of these documents are related to harbor security in general, whereas others only apply to specific security arrangements in the port of Antwerp. The study of these documents provided us with a first insight into the current situation of the port and the ways in which the four security phenomena are currently being dealt with in the different parts of the port area. Second, in-depth expert interviews were conducted with 32 respondents from 17 different public organizations that play a key role in the approach of at least one of the four security phenomena on which we focus in this study. A complete list of these organizations together with the geographical part of the port in which they operate can be found in Table 1 .

Within every organization we aimed at interviewing two or more knowledgeable respondents with expertise or experience in approaching one or more of the four security phenomena either at the strategic or at the operational level. Due to time and budget limitations, the following organizations could not be consulted: the Belgian intelligence and security services, the Belgian Coordination Unit for Threat Assessment (OCAD) and the private (security) companies working in the port. However, more insight into the role of these players was gained through interviews with other actors and a thorough study of documents. The semi-structured interviews were conducted by using one general and one specific questionnaire, which were both sent well in advance to the respondents for them to be able to prepare for the interview. The general questionnaire (see Appendix) was the same for all respondents and consisted of three types of questions: (i) questions with respect to the general tasks, objectives and priorities of the respondent's organization and the way in which these are approached, (ii) questions with respect to specific tasks, objectives and priorities in the port of Antwerp and the ways in which these are approached (eventually with collaboration agreements) and (iii) questions with respect to integral and integrated security within the port area. Part 1 of the general questionnaire comprised questions of types (i) and (ii), whereas Part 2 of the general questionnaire consisted of type (iii) questions. 
Table 1: Overview of organizations where in-depth interviews were conducted.

\begin{tabular}{|c|c|c|}
\hline & Organization & $\begin{array}{c}\text { Number of persons } \\
\text { interviewed }\end{array}$ \\
\hline & A. Not tied to one specific area within the port & \\
\hline 1 & Federal Crisis Centre (Belgian Ministry of Home Affairs) & 2 \\
\hline 2 & Customs (Belgian Ministry of Finances) & 1 \\
\hline 3 & $\begin{array}{l}\text { Department of Mobility and Public Works - Section Harbor } \\
\text { Policy (Flemish Regional Government) }\end{array}$ & 1 \\
\hline 4 & $\begin{array}{l}\text { Department of Mobility and Public Works - Section Pilotage } \\
\text { (Flemish Regional Government) }\end{array}$ & 1 \\
\hline 5 & General Directorate of the Federal Administrative Police & 1 \\
\hline 6 & Federal Maritime Police, section port of Antwerp & 3 \\
\hline \multirow[t]{2}{*}{7} & Antwerp Municipal Port Authority & 2 \\
\hline & B. Right bank of the port area & \\
\hline 8 & Province of Antwerp & 2 \\
\hline 9 & Public Prosecutor's Office, district of Antwerp & 3 \\
\hline 10 & Federal Judicial Police, district of Antwerp & 3 \\
\hline 11 & Federal Administrative Police, district of Antwerp & 3 \\
\hline \multirow[t]{2}{*}{12} & Local police, city of Antwerp & 2 \\
\hline & C. Left Bank of the port area & \\
\hline 13 & Province of Eastern-Flanders & 1 \\
\hline 14 & Public Prosecutor's Office, district of Dendermonde & 3 \\
\hline 15 & Federal Judicial Police, district of Dendermonde & 2 \\
\hline 16 & Federal Administrative Police, district of Dendermonde & 2 \\
\hline 17 & Local Police, municipality of Beveren & 1 \\
\hline Total & & 32 \\
\hline
\end{tabular}

The specific questionnaire was customized per actor and provided the opportunity for the respondents to elaborate on certain viewpoints, remarks, and considerations.

The information gathered and obtained through the study of documents and the interviews was processed using two analyses. First, an analysis was carried out at the level of the individual respondent. Each respondent received a detailed personal feedback report in which the content of the interview was summarized and organized in relation to the key themes of the analysis scheme (see Fig. 1). The reports were supplemented with references to relevant documents (legislation, policy documents, protocols, etc.) mentioned by the respondent during the interview or collected by the researchers in the first phase of the research. Sometimes remarks made by other respondents were added to the report (e.g. in the case of contradictory views or information). Respondents were asked to validate this report or, if necessary, to make changes and/or additions. This iterative process can be considered as a form of data triangulation between the documents, the interview data and the interpretations of the researchers. In the second (and final) phase, the information obtained was thematically analyzed in relation to the four above-mentioned security phenomena. 


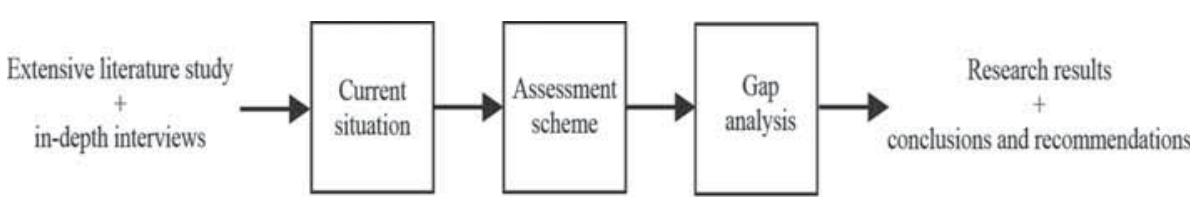

Figure 2: Schematic overview of research methodology.

Figure 2 illustrates a schematic overview of the research methodology and the way our study is presented in this article. We obtained through the extensive literature study in combination with the in-depth interviews, a picture of the current security arrangements within the Antwerp harbor. We then used the assessment scheme (see Fig. 1) to carry out a gap analysis based on the perceptions of the interviewees. In the next section, we summarize the main points of attention indicated by the respondents with respect to the four points of the assessment scheme. We mainly focus on the results and recommendations based on the gap analysis and provide additional background information wherever it is deemed necessary. To extensively describe the current arrangements in detail would make the paper unreadable and much too detailed.

\section{RESEARCH RESULTS}

\subsection{Port-related crime}

\section{Definition}

Currently, there is no unambiguous definition available of 'port-related crime' as a specific criminal phenomenon. However, the port is often used as a 'logistics gateway' for criminal organizations to distribute certain goods (drugs, cars, waste, etc.) and/or people within Europe or worldwide. Furthermore, port-related crime also involves crimes against businesses (e.g. burglary) operating within the port area. In order to integrate the approach of port-related crime by the different police forces operating in the port area (the local police forces of Antwerp, Zwijndrecht en Beveren, the federal judicial police forces of Antwerp and Dendermonde and the maritime police force), this phenomenon needs to be carefully mapped and clearly described. This analysis could form the basis for the specification of certain port-related criminal activities in the national and local security plans and, hence, a better division and coordination of tasks between the different police forces.

II. Communication structures

An integral approach to crime requires the different police forces and the administrative authorities (mayors) and judicial authorities (public prosecutors) under which they operate to coordinate their efforts. However, the existing consultation structures required by law - the District Investigation Consultation Platforms (one in the judicial district of Antwerp and one in the judicial district of Dendermonde) and the Local Security Council (one in each of three municipalities of the port area) - only cover a part of the port. Moreover, a number of important services in the port such as the Customs and the harbormaster are not (directly) represented in every one of these communication structures, because their duties do not primarily focus on fighting crime. However, as these bodies are constantly active in the port area, they do possess a lot of very interesting 
information that might be useful for crime-fighting purposes. We recommend the installation of a specific 'harbor security platform' which brings together the two judicial authorities in the port area, the different policing bodies (federal and local), the Customs and the harbormaster of the Antwerp Municipal Port Authority in order to better coordinate efforts in the fight against harbor-related crime.

Furthermore, the information exchange between different actors is currently often of an informal nature and, in this respect, it is worth thinking about a more formal structure such as a shared information crossroads databank. However, the legal possibilities and limitations of such an exchange of information between Customs, the police and private companies need to be examined in more detail first. Such an investigation was beyond the scope of this study.

III. + IV. Responsibilities and handling.

Approaching port-related crime in a reactive way is first and foremost a task for the police forces (in the first place the federal judicial police, but to a lesser extent also the criminal investigation section of the local police forces) who carry out criminal investigations under the supervision of a public prosecutor or an investigating judge. In order to achieve a more integral approach to this type of crime, however, support and cooperation with other partners is indispensable. In the port, the police force's partners are Customs and the harbormaster's services and, to a lesser extent, private companies. By carrying out inspections in the port area, the former two can assist the police in enhancing the probability of criminals getting caught. The role of private companies is predominantly situated in the domain of situational crime prevention (e.g. protecting their properties by taking techno-preventive measures). A number of points for attention were identified through the in-depth interviewing.

The Customs and the harbormaster's services do not always have the required capacity and/or sufficient time to proactively carry out inspections and patrols within the harbor area. In this respect, a better collaboration and the establishment of mixed teams consisting of all the inspection authorities that operate in the port, is often recommended. An example often mentioned in this case is the Expert Center Harbor in the port of Rotterdam, where several actors such as the seaport police, the National Crime Investigation Service and the Customs, work together to tackle crime in the Rotterdam port area by combining expertise and by carrying out joint actions [6].

Various police services operate in the port: the maritime police, three local police corpses and the federal police services of two judicial districts. In order to tackle port-related crime, it is essential that the various police services work well together. Although the cooperation in practice is good, a number of points for attention were mentioned which could be improved upon:

1. Protocols have been signed which agree that basic policing in the port is assured by the maritime police, except in the municipality of Zwijndrecht (where it is assured by the local police of Zwijndrecht). In a large part of the port area, the maritime police (which is a specialized policing body) is thus taking up basic policing tasks that are normally the competence of the local police forces. This establishes a need for more coordination between the local police forces and the maritime police. In practice, the withdrawal of the local police forces from basic policing tasks in the port area has also led to a diminished attention for port-related crime on their behalf.

2. The maritime police has a very wide range of tasks: border control and surveillance, basic policing in the port, maritime policing (police patrols by boat), specialized and 
subsidiary support to the federal and local police forces and inspection of specific portrelated laws and regulations. Moreover, the area which it polices, which also includes all navigable waterways outside of the Antwerp port, has significantly grown as a result of the expansion of the Antwerp port. To date, the resources of the maritime police have not yet been adapted to reflect this reality.

A last major challenge as regards tackling port-related crime is the collaboration and distribution of tasks between the two federal judicial forces (Antwerp and Dendermonde) who both carry out criminal investigations in the port area under the authority of two different public prosecutors (Antwerp and Dendermonde). First, we can conclude from the interviews that the current cooperation (as regulated by a special memorandum) mainly relates to the distribution of operational tasks among the two federal judicial police forces. No significant issues were mentioned by the interviewees in our study regarding this distribution of tasks. Nevertheless, this situation leads to an increased risk that different investigation strategies are developed in different parts of the port. Moreover, organizational pathologies in police intelligence can arise such as duplication of information or institutional friction (the difficulties of moving information across institutional boundaries). In the long term, it might be better to create a single police entity for the entire port in the framework of the principle of 'unity of land, unity of command'. There is some discussion about how this principle should be put into practice, however. On the one hand, some respondents have suggested that this entity should be a new police entity that would be responsible for basic policing as well as for specialized policing and should also carry out administrative and judicial tasks. However, with respect to criminal investigations, police forces in Belgium operate under the supervision of a judicial authority (the public prosecutor or an investigating judge). Since the port area is situated in two judicial districts, this unified police would still have to operate under different authority structures. On the other hand, this principle might also be translated as the main responsibility for investigating port-related crime being assigned to one federal judicial police service (either of Antwerp or of Dendermonde) operating under the supervision of one public prosecutor's office (either that of the judicial district of Antwerp or that of Dendermonde).

\subsection{Threats}

\section{Definition}

The definition of 'threat' provided by Belgian national law includes the following: espionage, terrorism, extremism, proliferation, harmful sectarian organizations, criminal organizations and interference. Although there is currently no evidence of any threats, it is not inconceivable that the port and its critical infrastructure may be the object of threats. Threats relating to terrorism and extremism are easily thought of, but the definition also includes other forms of intentional acts which may disrupt or destroy the port's operations based on criminal motives (hacking, or hostage situations, for example) or based on the tendency to maximize the number of casualties without taking cover or hostages.

II. Communication structures

An important meeting and consultation platform on maritime security is the Local Committee for Maritime Security. The port of Antwerp's local committee on maritime security consists of the harbormaster of the Antwerp Municipal Port Authority (Chairman), the local police forces of Antwerp, Zwijndrecht and Beveren, the maritime police, Customs 
and the National Security and Defense (Provincial Command Antwerp). This committee may be expanded in order to obtain an integral and integrated approach. For example, the platform should seek collaboration with the consultation platforms for emergency planning, i.e. the municipal or provincial safety cells (see section 4.3). This has already partially been carried out given that a number of the committee's members are also represented in these safety cells. However, a number of authorities and services which have an important role to play in the decision-making process for certain administrative and judicial measures in the field, still do not have representation (e.g. the mayor and the Public Prosecutor). In order to be representative of the entire port, a representation or link with the competent actors in the Province of Eastern-Flanders and/or the judicial district of Dendermonde must also be achieved.

III. + IV. Responsibilities and handling

Similar to port-related crime, threats require predominantly not only preventative and reactive measures but also proactive ones. The first two measures focus on controlling the actual threat. The preventative aspect has been developed in more detail as a result of the International Ship and Port Facility Security Code (or ISPS Code). Following the transposition of this code into an EU Directive, private companies have drafted security plans based on risk analyses, with all kinds of measures designed to protect and secure their port facilities and often their entire site. The EU Directive ensures that there are also measures in place designed to secure the port as a whole. The new legislation in the framework of the European Program for Critical Infrastructure Protection stimulates the preventative aspect and primarily places responsibility for it with the operator. There are, however, still a few points for attention in the preventative measures:

1. In the first place, further thought and increased investments are needed with regard to the digitalization of the information contained in the security plans. However, it is important to work with the existing databases as much as possible and to ensure that we will not be confronted in the long term with parallel databases that are not compatible with one another. This latter problem has been described by Sheptycki [7] as 'digital divide'.

2. Secondly, it is recommended that the security plans tie in as much as possible with the emergency and intervention plans and/or that they are coordinated with them. This coordination will not be an easy task given that both plans are being developed based on different philosophies but also because the security plans of the ports and the port facilities are strictly confidential. Certain steps towards a rapprochement are being taken, but this continues to be a point of attention. In terms of information management, it would be interesting to coordinate both plans more and to gather them in a secured crossroads databank.

3. Thirdly, continuing to work on raising the awareness of port security personnel via training or through educational courses is needed.

The reactive approach comprises all the measures relating to threat management when a threat becomes real and/or is actually carried out. The general consensus is that these measures are sufficiently in line with the principles and structures for the handling of emergencies (see also section 4.3) in view of the fact that the response undoubtedly also requires administrative measures.

In order to achieve an integral approach, it is essential to continue to invest in the development of measures which contribute to the early detection of threats. As with port-related 
crime, the success or failure of this proactive approach depends on the development of an effective information status and exchange. At the federal level, the anti-terrorism unit OCAD is responsible for evaluating the information supplied by various services such as the intelligence and security services, the federal and local police and the Customs. In order to continue to better develop this information status, it is however also important that information is gathered in private companies. The Early Warning System (EWS) already contributes to this goal. The EWS is a public-private information network at the national level where private companies are encouraged to report suspect behavior and events to the local police. It was set up by the police in collaboration with the Federation of Enterprises in Belgium. Such initiatives are also being taken and proposed at the local level.

Various authorities and services are involved in protecting the port against threats. The harbormaster as well as other bodies such as the maritime police and Customs significantly contribute to stimulating, developing and maintaining preventative protection and security measures in the port. In order to ensure that the threat-oriented approach (with an emphasis on protection and security) is completed with a cause-oriented approach (tracking down perpetrators and investigating phenomena), a more far-reaching integration of the administrative and judicial processes of the police services is required. This, however, is more of a point for attention at the national level. An important point for attention in terms of the division of competences is the manner in which the local authorities and services will organize themselves when confronted with a threat that becomes real.

\subsection{Emergency situations}

\section{Definition}

What constitutes an 'emergency situation' is unambiguously defined by Belgian national law and therefore similar for all actors within the port area: 'each event which has (or could have) damaging consequences for societal life, such as a serious disruption of public security, a serious treat for the health and life of persons, or a serious treat for material interests, and which necessitates a coordination of different emergency services to neutralize the treat or to limit its consequences'. Hence, the interviewed experts did not mention a definition problem for this security phenomenon.

II. Communication structures

In the port of Antwerp, two provincial safety cells (one in Antwerp and one in Eastern-Flanders) and three municipal safety cells (in Antwerp, in Zwijndrecht and in Beveren) are responsible to prepare emergency situations. They constitute platforms where different actors who are concerned with safety communicate and consult together. The composition of these safety cells is determined by Belgian national law. The following actors have to be represented in each safety cell: the mayor and the municipal civil servant responsible for emergency planning (in the municipal safety cell) or the governor and the provincial civil servant responsible for emergency planning (in the provincial safety cell), a representative of the fire brigade, a representative of the police, a person representing medical and psychosocial services, a person responsible for logistic assistance and a person responsible for information/communication. Besides these legally determined actors, in Eastern-Flanders, as well as in Antwerp, the provincial safety cells are complemented with other public services and private companies. However, only in the Antwerp provincial safety cell, explicit representation is present from the maritime police, the Customs and the municipal port company. In the 
Eastern-Flanders safety cell, the left bank part of the harbor is represented by the fire brigade commander of Beveren, the local police of Beveren, the head of the federal judicial police of Dendermonde and the private company Ashland.

In view of the expansion of the harbor area at the left bank of the river Scheldt, it would be preferable (according to the interviewees) to include direct representation of certain harbor actors, such as the harbor captain, in the provincial consultations of Eastern-Flanders regarding emergency planning. However - and similar to what we suggested above in the case of port-related crime (see section 4.1) - a cross-border consultation structure covering the whole port area should be considered.

III. Responsibilities

Our study revealed the following items of consideration, concerning the collaboration between different actors and their responsibilities in emergency situations.

Although the leadership of police operations during emergency situations is legally arranged, these activities are often seen as insufficiently flexible and adaptable to the specific complex context of the port area. Collaboration between police services is locally arranged more in depth, and the arrangements differ between the left bank and the right bank. For example, the maritime police takes up a leading role during emergency situations on the left bank (because they are more familiar with the port area than the local police or the federal judicial police operating on the left bank), but an operational role during emergency situations on the right bank (where the chief constable of the local police of Antwerp or the head of the federal judical police of Antwerp take up the leading roles). One possible solution to these differing arrangements within the same port area which was suggested by some respondents is to install one police service responsible for the entire port area, a 'harbor police'. However, police forces in Belgium operate under the supervision of a judicial (the public prosecutor) or administrative authority (the mayor). Since the port area is situated in three municipalities (three mayors) and two judicial districts (two public prosecutors), this unified harbor police would still have to operate under different authority structures. The assignment of a unified 'harbor police' to one authority structure is politically sensitive and therefore difficult to realize.

The division of competences and capacities between different administrations and services as regards preparation for, and management of, emergency situations located on some border, or having an impact on areas being subject to other administrations or services, can be noticed. Such cross-border emergency situations are, however, very realistic in the Antwerp harbor area. Regarding preparatory actions, different actors need to be aware of each other's procedures and means, and ideally, the procedures and means are identical. Furthermore, common emergency plans for the left bank and the right bank would be recommendable, since uniform procedures and emergency exercises, as well as identical communication protocols, etc., would lower the likelihood of mistakes and miscommunications, and it would increase the quality of the emergency plans (resulting from continuous improvement of the uniform plan). An option to solve the (potential) cross-border problems (due to miscommunication, non-transparent responsibilities, etc.) is to assign a 'pilot-governor' who is in charge of cross-provincial emergency situations.

IV. Handling

Belgian national legislation offers a clear framework as regards the handling of emergency situations. An integral way of dealing with emergency situations in the port area is explicitly encouraged and is translated into a risk cycle. Within this cycle, mainly the preparatory measures (risk identification activities and the elaboration of emergency 
plans and procedures) and the reactive measures (management and control of emergency situations) are concretely worked out. In the reactive phase, the general principle holds that the management is handled at the most appropriate level. Three possible levels exist: the municipal, the provincial and the federal (national) level. The management of an emergency situation at the municipal or provincial level is carried out by an operational coordination structure or a so-called CP-Ops and an administrative coordination structure or a so-called CC. The CP-Ops is headed by an operational leader (fire brigade commander, municipal police or medical doctor, depending on the emergency situation at hand), whereas the $\mathrm{CC}$ is headed by the mayor or the governor. Managing an emergency situation at the national level has its own structure with an evaluation cell, a policy cell, and an information cell. An emergency situation at the port can become the responsibility of the national level when, for instance, two or more provinces are involved, when there are so many victims or when there is so much danger in a large area that the need arises to inform the entire Belgian population. To prevent the occurrence of emergency situations, investments in prevention measures are essential, for example sufficient controls on existing regulations. Several interviewees mentioned that more attention needs to be devoted to curative measures, i.e. all measures needed to return to normal circumstances. Although the preparatory and reactive measures are worked out sufficiently in detail, our in-depth interviewing results indicate that certain challenges remain, such as a legally obliged framework for internal emergency plans (which are emergency plans of individual companies), applicable to all companies (and not only to Seveso companies as is currently the case), or such as the alignment and optimization of traffic circulation plans of the left bank and right bank of the harbor area.

\subsection{Events and incidents}

\section{Definition}

There seems to be no confusion between and among the interviewees about the definition of events and incidents. In the port area, large traffic accidents and major accidents are important examples of 'sudden and unexpected events which require immediate and coordinated onsite policing'. As far as planned events which might jeopardize public order, safety and/or health, the examples are more varied. These include small-scale (e.g. the visit of a VIP) or large-scale (e.g. festivals) events, as well as strikes or demonstrations, whether they attract a large crowd or not.

II. Communication structures

Planned events and demonstrations are managed with coordination meetings (which are organized by provincial administrations) in which all the relevant actors (municipality, local police force, public prosecutor, emergency services, etc.) including the event organizer, are represented. During these meetings, the risks are mapped, several scenarios are developed and agreements are made in terms of police and civilian security (and safety). These coordination meetings are also used to make agreements between the administrative (mayor) and judicial authorities (public prosecutor) when judicial action (such as a police report or an arrest) might be necessary. However, these agreements should be more clearly communicated beforehand to all the parties involved and should also be documented (e.g. included in the events plans). In Antwerp, a specific consultation platform has been established to this end: the so-called Advisory Group on Event Safety and Security. The agreements and principles are in line with the structure of the emergency 
plans given that the members of the Advisory Group are virtually the same actors that have been appointed to the municipal safety cell (see above) and that this group also reports to this cell.

III. + IV. Responsibilities and handling

With regards to events management, the principles of emergency and intervention planning are also applied to the agreements in terms of police and civilian security during planned events. The principle of negotiated management is applied for the management of incidents and events and starts from the premise of the protection and management of events and/or large crowds. The emphasis is also laid on an integral approach with attention to protection, prevention, de-escalation (with possible regulation and repression) and aftercare.

As is the case with emergency planning, a variety of actors are involved in the management of incidents and events. Generally, they cooperate well according to the interviewees. Our qualitative study reveals the following main points of interest:

1. The administrative authorities are responsible for ensuring public order. Generally, as is the case in the port, this is the task of the municipal authorities (the mayor). However, since the port area is located in three municipalities, there should be sufficient communication and consultation to prevent the various municipal administrations from issuing contradicting regulations or measures.

2. Police are responsible for implementing these measures according to the principles of negotiated management. Generally speaking, the police cooperation between the various police forces in the port (local police, maritime police, federal judicial and administrative police) is smooth, and for the time being no significant issues have been identified. It is worth noting that the maritime police's role varies, depending on whether they are operating on the left or right bank, as is the case in emergencies (see section 4.3).

3. It is not inconceivable that an event may take place in the entire port (e.g. a general strike or the visit of a VIP). The police usually assigns this task to the head of the federal judicial police, but the chief constable of the local police may also be in charge of coordinating and leading operations. This assignment occurs on a case-by-case basis, in consultation with the other authorities and services. Up until now this has always gone well and formalization was not considered a necessity.

\section{CONCLUSIONS AND RECOMMENDATIONS}

Four security phenomena were investigated in the Port of Antwerp area in Belgium: (i) portrelated crime, (ii) threats, (iii) emergency situations and (iv) events and incidents. For each of these phenomena, administrative, authority, judicial and police arrangements were studied through qualitative research. Our study started from the premise that the ways in which these multi-actor arrangements tackle each of the four security phenomena should be sufficiently integral and integrated. We conceptualized four conditions (definition, communication, responsibilities and handling) that have to be taken into account when implementing such an integral and integrated approach. Then we used a case study design - combining two main data collections methods (study of relevant documents and qualitative interviews with experts) - to examine the extent to which these conditions are currently met in the Port of Antwerp, and how, if necessary, improvements could be made. Our results indicate that present arrangements can be largely improved, both within the existing setting as out of current administrative, authority, judicial and police boundaries of competence and responsibility. 
Within the existing setting, making arrangements more uniform and transparent for all actors, a rearrangement of the tasks and responsibilities of maritime police, together with more intensive collaboration, communication and information exchange between different parties in security matters, seems to be the most important recommendation. If thinking out of the existing settings and not taking into account existing legislation, we recommend to establish the port of Antwerp area as one separate region with a single administrative, authority, judicial and police boundary. Within such a region, a crisis manager may be responsible for emergency planning issues, while competences and responsibilities of authorities and judicial and police services are also made uniform and according to the "unity of land, unity of command' principle.

\section{REFERENCES}

[1] Ten Brinke, W.B.M., Saeijs, G.E.M., Helsloot, I. \& Van Alphen, J., Safety chain approach in flood risk management. Municipal Engineer, 161(2), pp. 93-102, 2008. doi: http://dx.doi.org/10.1680/muen.2008.161.2.93

[2] Brewer, G. \& de Leon, P., The Foundations of Policy Analysis, Dorsey Press: Homewood, IL, 1983.

[3] Altiok, T., Port security/safety, risk analysis and modelling. Annals of Operations Research, 187, pp. 1-3, 2011. doi: http://dx.doi.org/10.1007/s10479-011-0849-8

[4] Crawford, A., The governance of urban safety and the politics of insecurity. Urban Safety: Problems, Governance and Strategies, eds. K. van der Vijver \& J. Terpstra, Institute for Social Safety Studies. University of Twente: Enschede, pp. 65-85, 2004.

[5] Yin, R.K., Case Study Research: Design and Methods, 4th edn, Applied Social Research Series, Vol. 5, Sage Publications: Thousand Oaks, CA, 2009.

[6] Van Sluis, A., Marks, P., Gilleir, F. \& Easton, M., Nodal security in the ports of Rotterdam and Antwerp. Beyond Fragmentation and Interconnectivity: Public Governance and the Search for Connective Capacity, eds. M. Fenger \& V. Bekkers, IOS Press: Amsterdam, pp. 73-94, 2012.

[7] Sheptycki, J., Organizational pathologies in police intelligence systems: some contributions to the lexicon of intelligence-led policing. European Journal of Criminology, 1(3), pp. 307-332, 2004. doi: http://dx.doi.org/10.1007/s10479-011-0849-8

\section{APPENDIX: GENERAL QUESTIONNAIRE.}

\section{Part 1: Current state of affairs}

1.1 General objectives and tasks of the organization

- What are the most important objectives and tasks of your organization?

- What are the most important priorities of your organization? What are the most important problems your organization is currently being confronted with? Are those new or old problems?

- How are these priorities and problems being approached?

- Which other actors or organizations do you collaborate with? Are these new or old collaborations?

1.2 Specific objectives and tasks related to the port area

- To what extent are the objectives and tasks of your organization related to the port of Antwerp? 
- To what extent are the priorities and problems of your organization related to the port?

- How are these port-related priorities and problems being approached?

- Which other actors or organizations do you collaborate with to approach portrelated priorities and problems?

\section{Part 2: Integral and integrated security}

- Which security phenomena in the port of Antwerp definitely need to be approached in a more integrated and integral way according to you?

- What does such an integral and integrated approach ideally look like? How can security phenomena in the port be approached in a better way?

- What are the most important conditions that need to be fulfilled in order to arrive at a truly integral and integrated approach?

- What are currently the most important problems, obstacles or barriers that stifle the implementation of an integral and integrated approach of security phenomena in the port (with respect to the definition of problems, communication and division of responsibilities between different actors, handling)?

- Which actors or organizations need to be more involved in the approach of security phenomena in the port? 